\title{
A new outbreak of fox rabies at the Russian-Mongolian border
}

\section{Dear Editor,}

Lake Baikal and its neighboring territories are an intermediate zone for the "steppe" and "arctic-like" rabies virus lineages in Russia. After the elimination of dog-mediated rabies during the early 1980 s, this area remained rabies-free for over 25-30 years. A sudden reappearance of rabies occurred in this zone in the Republic of Buryatia in 2011-2012. A marginal part of the Mongolian steppe penetrates the Siberian taiga forests in this area, and human and animal rabies have been repeatedly recorded in the Republic of Buryatia from the end of the nineteenth century till 1981. Among the various animals of this region, rabies was documented mainly in dogs, farm animals, and occasionally in wolves, but never in foxes (Botvinkin et al., 2008).

The surveillance of animal rabies was performed by the regional veterinary service using data from the local veterinary laboratory. The first case of recurrence of rabies in the Republic of Buryatia was documented at the end of February in 2011 (Zakamensk district, N50 25'27" E104 $\left.{ }^{\circ} 8^{\prime} 44^{\prime \prime}\right)$ and the last case in 2011 was confirmed in a dog in the middle of April. No other suspected cases were reported until the beginning of 2012. However, in February 2012 rabies re-emerged in the same area. The disease was diagnosed predominantly in wild canines $(61 \%)$ while some cases were also diagnosed in cattle. All these cases were registered in the narrow valley of the Dzhida River in the forest mountain region.

The rabies cases of 2011 were documented in two distinct locations about $30 \mathrm{~km}$ apart. The following year, several new cases were recorded around the previous locations with the most distant point being $80 \mathrm{~km}$ to the west from the place of the first cases. The Republic of Buryatia has a common border with Mongolia where rabies is known to occur in wild as well as domestic animals (Blancou, 2008; Boldbaator et al., 2010), and all cases recorded in the Republic of Buryatia during 2011-2012 occurred within 30-40 km from the Mongolian border. The nearest areas in the Asian part of Russia (Krasnoyarsk region and Republic of Tyva) that are affected by fox rabies are located more than $500 \mathrm{~km}$ to the north-west and are separated from the Republic of Buryatia by high mountain ridges and cannot be a source of infection for the Republic of Buryatia area.
Brain samples from rabies-suspected animals were collected in the southern regions of the Republic of Buryatia from February to April $2011(\mathrm{n}=32)$ and in February $2012(\mathrm{n}=5)$. Rabies was confirmed in 18 animals (Table 1) by direct fluorescent antibody test (Dean et al., 1996) by using commercially available reagents (Federal Center for Toxic and Radiation Safety of Animals, Russia). Three-week old inbred white mice were used for virus isolation according to the method recommended by the WHO (Koprowsky, 1996). Total RNA was extracted from the brain tissue $(10 \%$ suspension in saline) by using the Riboprep kit (ILS Ltd., Russia). Amplification of the complete nucleoprotein $(\mathrm{N})$ genes of rabies virus isolates was performed via reverse-transcription polymerase chain reaction (RT-PCR) by using the Amplisens kit (ILS Ltd., Russia) and PCR kit (Syntol, Russia) with primers described elsewhere (Goto et al., 1994; Smith, 1995). For comparative analysis, we used rabies virus isolate sequences from neighboring territories. The RT-PCR products were sequenced using ABI Prism Big Dye Terminator v.1.1 Cycle Sequencing Kit (Applied Biosystems, USA) and the Genetic Analyzer 3130 (Applied Biosystems, Japan). Sequences of all 12 virus isolates were confirmed based on sequences of the strains' passages. The sequences (1353 bp) were aligned in BioEdit v. 7.0.5.3 (Hall, 1999). Phylogenetic analysis was performed using MEGA 5 (Tamura et al., 2011) by the maximum likelihood method.

Phylogenetic analysis of rabies virus isolates from the Republic of Buryatia (Figure 1) showed that they were almost identical to each other and very similar to the isolates from Mongolia. In addition, they belonged to the broadly distributed group of rabies viruses that circulate among red foxes and corsac foxes in the steppe and forest-steppe zones of Eurasia: from Eastern Europe to Mongolia (Boldbaator et al., 2010; Botvinkin et al., 2008; Kuzmin et al., 2004; Poleshchuk et al., 2013). Nucleotide sequences ( $N$ gene) analysis of the isolates from 2011 showed that phylogenetically, the viral isolates from the Republic of Buryatia were very similar to the isolates from Mongolia with only 7-15 neutral nucleotide substitutions. Comparison with the isolates from 2011-2012 in the Republic of Buryatia detected only two nucleotide substitutions in $N$ gene. This data suggested that the rabies virus harbored by wild animals within the 
Dzhida River valley did not undergo any genetic alterations in one year. In addition, isolates from the nearest rabies-enzootic regions of Russia also belonged to this group; however, they were phylogenetically distant from the isolates originating in the Republic of Buryatia and Mongolia.

The present rabies outbreak in the Republic of Buryatia presented the most distant northeastern isolates originating in the Republic of Buryatia propagation of rabies virus infection in foxes in the Asian part of Russia. Based on available molecular, epidemiologic, and spatio-temporal data, we propose that the most likely reason for the re-emergence of rabies in the Republic of Buryatia is a drift of the rabies virus from Mongolia. Frozen rivers that cross the mountain ridge at the border between the Republic of Buryatia and Mongolia could serve as environmental channels for reservoir animals. Most likely rabies has been introduced in the Republic of Buryatia by foxes or wolves during the winter of 2011, and further infection disseminated along valleys of various rivers, mainly among foxes with occasional infection in wolves, badgers, and domestic animals.

In 2002, a similar outbreak was documented in another Asian region of Russia approximately $12^{\circ}$ to the West (south part of Krasnoyarsk region, $\mathrm{N} 53^{\circ} \mathrm{E} 63^{\circ}$ ) from Zakemensk District. During this outbreak, the rabies virus of the "steppe" lineage was first isolated in our laboratory from wolves (Botvinkin et al., 2006). Ten years later, both fox rabies and "steppe" rabies viruses were detected predominantly in this region (Poleshchuk et al., 2013).

The main aim of this study is to determine whether the recent fox rabies outbreaks represent an occasional fluctuation in the borders of rabies virus habitat or it is

Table 1. Rabies positive wild and domestic animals in the Republic of Buryatia, 2011-2012.

\begin{tabular}{|c|c|c|c|c|c|c|}
\hline \multirow{2}{*}{ Year } & \multicolumn{6}{|c|}{ Number of rabid animals (laboratory confirmed cases) } \\
\hline & Red fox & Wolf & Badger & Cattle & Dog & Total \\
\hline 2011 & 7 & 1 & 1 & 3 & 1 & 13 \\
\hline 2012 & 1 & 1 & 0 & 3 & 0 & 5 \\
\hline Total & 8 & 2 & 1 & 6 & 1 & 18 \\
\hline
\end{tabular}
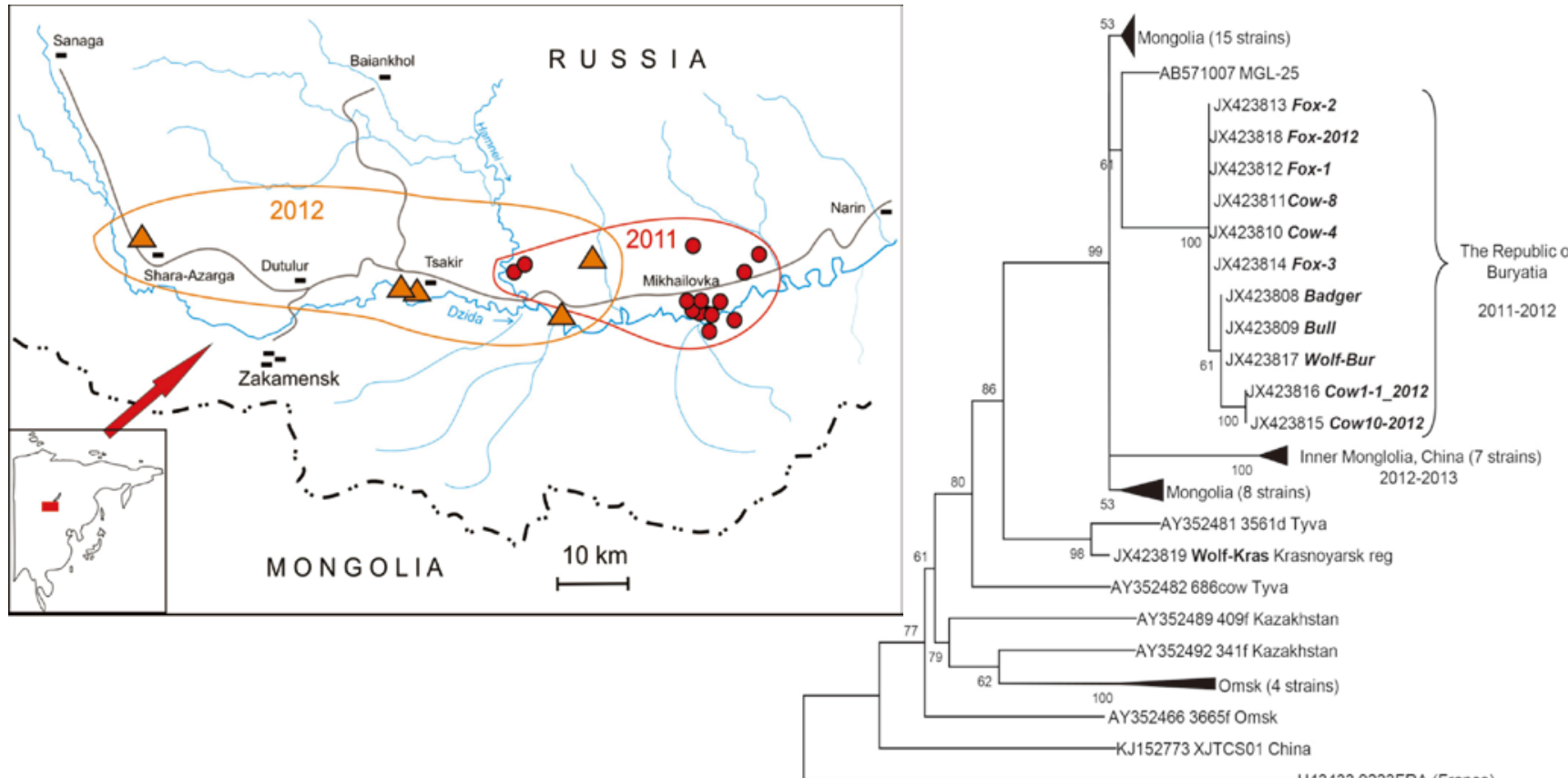

$\longmapsto 0.005$

Figure 1. Maximum likelihood (ML) phylogenetic tree analysis based on the entire $N$ gene. Twelve rabies virus isolates within this study are in bold font, and the GenBank accession numbers are shown. The 11 isolates from the Republic of Buryatia are italicized. Bootstrap values are presented as key nodes and branch lengths are drawn to scale. Map: spatio-temporal spreading of animal rabies cases along the Dzhida River valley in 2011-2012 (circles: 2011; triangles: 2012). 
a step toward widespread dissemination of fox rabies in Asia. According to data presented at the conference "Towards the elimination of rabies in Eurasia" (Fu, 2008; Gruzdev, 2008; Seimenis, 2008) at the beginning of the twenty-first century, fox rabies was largely unknown in the Far East while being endemic in Eastern Europe. Further, the incidence of fox rabies decreased in Central and Western Europe, while a progression occurred in the Middle East and Central Asia. Therefore, further researches are necessary on the intermediate zone between the two different rabies virus lineages in Central Asia.

\section{FOOTNOTES}

We thank the veterinarians at Zakamensk and the local administration of the Republic of Buryatia. This work was supported by the Federal Service for Surveillance in the Sphere of Consumers' Rights Protection and Human Welfare (Rospotrebnadzor). The authors declare that they have no conflict of interest. All animal experiments were performed in accordance with Regulations for Proper Conduct of Animal Experiments (confirmed by order of the Ministry of Health USSR N 755 12-8-1977).

Renat V. Adelshin ${ }^{1,2 \otimes}$, Olga V. Melnikova ${ }^{1}$, Yulia N. Trushina ${ }^{1}$, Alexander D. Botvinkin ${ }^{3}$, Tatyana I. Borisova ${ }^{1}$, Evgeny I. Andaev ${ }^{1}$, Dmitry B. Verzhutsky ${ }^{1}$, Albert S. Khangazhinov $^{4}$, Sergey V. Balakhonov ${ }^{1}$

1. Irkutsk Anti-Plague Research Institute of Siberia and the Far East, Irkutsk 664047, Russian Federation

2. Biology Institute of Irkutsk State University, Irkutsk 664025, Russian Federation

3. Irkutsk State Medical University, Irkutsk 664003, Russian
Federation

4. Regional Veterinary Laboratory, Ulan-Ude 670047, Russian Federation

$\triangle$ Correspondence:

Phone: +7-3952-220135, Fax: +7-3952-220140,

Email: adelshin@gmail.com

ORCID: 0000-0003-3690-3992

Published online: 11 August 2015

\section{REFERENCES}

Blancou JB. 2008. Dev Biol (Basel), 131: 3-15.

Boldbaator B, Inoue S, Tuya N, et al. 2010. Jpn J Infec Dis, 63: 358-363.

Botvinkin AD, Kuzmin IV, McElhinney LM, et al. 2006. Dev Biol (Basel), 125: 79-90.

Botvinkin AD, Otgonbaatar D, Tsoodol S, et al. 2008. Dev Biol (Basel), 131: 199-205.

Dean DJ, Abelseth MK, Atanasiu P. 1996. In: Laboratory techniques in rab ies, 4-th Edition. Meslin FX, Kaplan MM., Koprowski H (eds). Geneva: World Health Organization, pp. 88-93.

Fu ZF. 2008. Dev Biol (Basel), 131: 55-61.

Goto H, Minamoto N, Ito H, et al. 1994. Virus Genes, 8: 91-97.

Gruzdev KN. 2008. Dev Biol (Basel), 131: 37-42.

Hall TA. 1999. Nucl Acids Symp Series, 41: 95-98.

Koprowsky H. 1996. In: Laboratory techniques in rabies, 4-th Edition. Me slin FX, Kaplan MM, Koprowski H (eds). Geneva: World Health Organi zation, pp. 80-86.

Kuzmin IV, Botvinkin AD, McElcinney LM, et al. 2004. J Wildl Dis, 40: $617-631$.

Poleshchuk EM, Sidorov GN, Gribencha SV. 2013. Vopr Virusol, 3: 9-16. (In Russian)

Seimenis A. 2008. Dev Biol (Basel), 131: 43-53.

Smith JS. 1995. In: Manual of Clinical Microbiology. Murray P, Baron E, Pfaller M, et al. (eds). Washington, D.C.: American Society for Microbi ology, pp. 997-1003.

Tamura K, Peterson D, Peterson N, et al. 2011. Mol Biol and Evol, 28: 2731-2739 